\title{
Reading Interest to Millennial Students: Reading Self-Concept and Perceptions of Parental Involvement as Predictors
}

\author{
Roy Gustaf Tupen Ama, Rahma Widyana* \\ Faculty of Psychology, University of Mercu Buana Yogyakarta, Jl. Ringroad Utara, Condong Catur, Depok, Yogyakarta, Indonesia \\ *Corresponding author: rahma@mercubuana-yogya.ac.id
}

Article history: Received: 11 January 2020 Received in revised form: 28 June 2020 Accepted: 10 May 2021 Published online: 09 August 2021

\begin{abstract}
Purpose - this study aims to determine the relationship between self-concept of reading with reading interest in elementary school students; to determine the relationship between perceptions of parental involvement with reading interest in elementary school students; and to find out the relationship between selfconcept of reading and perceptions of parental involvement in stimulants with reading interest. Methods - This research uses a correlational quantitative method. In this study, researchers used a scale, there are reading interest scale, the scale of self-concept reading, and the scale of perception of parental involvement. The sample in this study was 47 elementary school students. The sampling technique used purposive sampling with the characteristics of male and female students of elementary school, grades 3, 4 and 5, ages 8 to 11 years, living with parents and having good reading fluency. The analysis used is Pearson product moment correlation analysis and regression analysis. Findings - the results of the analysis show (1) There is a positive relationship between self-concept of reading with reading interest in students with a correlation coefficient $\left(\mathrm{r}_{\mathrm{xy}}\right)$ of $0.652(\mathrm{p}<0.01)$ with a contribution of $42.5 \%$; $(2)$ there is a positive relationship between the perception of parental involvement with reading interest in students with a correlation coefficient $\left(\mathrm{r}_{\mathrm{xy}}\right)$ of $0.697(\mathrm{p}<0.01)$ with a contribution of $48.6 \%$ and there is a relationship between the concept of self-reading and perception of parental involvement stimulants with interest in reading with a value of $\mathrm{r}=0.690 ; \mathrm{F}=28,383 ;(\mathrm{p}<0.01)$ with a contribution of $56.3 \%$ to interest in reading. The score of reading interest category is in the medium category with $83.00 \%$, while the self-concept reading variable is in the high category with $59.70 \%$ and the perception variable of parental involvement is in the medium category with $93.00 \%$. The findings of this study indicate that the importance of parental involvement and reading selfconcepts in students increases student reading interest.
\end{abstract}

Keywords: Reading Self-Concept; Perceptions of Parental Involvement; Reading Interest, Millenial Students, Elementary School Students

(C) 2021 Penerbit UTM Press. All rights reserved

\subsection{INTRODUCTION}

Education is inseparable from the learning process. Learning is a multidimensional process that involves interactions in which there are interests and motivations that contain values, goals, beliefs in learning and are influenced by cognitive processes (Chen, Zhu \& Chen, 2014) . One of the best ways to learn is by reading. According to the Indonesian Central Statistics Agency (BPS), a survey conducted in 2015 showed that $91.47 \%$ of school-age children preferred watching television and $13.11 \%$ of school-age children preferred reading (Ministry of Education \& Culture, 2018). In general, based on data from the Central Statistics Agency in 2012 showed that as many as 91.58 percent of Indonesian people aged 10 years and over preferred to watch television and only around 17.58 percent of people who liked to read books, newspapers or magazines. (Humas, 2016). Technology advances information and communication have become a barrier to children's interest in reading (Bangsawan, 2018). Digital media has now become a distraction for Indonesian children today. This can be seen from their daily activities which are more often spent in front of television and gadgets because the media is more attractive to them (Yaumi, 2014).

Research conducted by the Center for Education and Culture Policy Research, (2019) results that of thirty-four provinces in Indonesia, 9 provinces $(26 \%)$ fall into the category of moderate literacy activities (delivery index figures $40.01-60.00$ ); 24 provinces (71\%) fall into the low category $(20.01-40.00)$; and 1 province $(3 \%)$ is in the very low category $(0-20.00)$. It means that most provinces are in the low literacy level and none of the provinces are in the high and very high level of literacy activity (index value between 60.01 80.00 and 80.01 - 100.00). (Noviriani et al., 2019).

This is in line with the results of research conducted by Nursalina and Budiningsih (2014) resulting that as many as 32 subjects studied from the entire population have a low level of interest in reading. The low interest in reading from 32 subjects was due to the awareness of reading, attention to attention in reading, feeling of pleasure and frequency in reading which were classified as low. A study conducted by Rachman, Rachman and Rachmawati (2017) on a case study of reading interest in elementary school students resulted that the reading interest of grade 3 students in Anyelir State 1 Depok Elementary School was still low, this can be seen from the results of a survey conducted to all grade 3 students with the total sample of 154 shows that in total no more than 55\% of students did reading activities. However, 55\% of students stated that reading was an activity that had been carried out long ago. Research conducted by Antari et al. (2016) regarding descriptive studies of elementary school students 'interest in reading in the city of Tangerang resulted in the 
category of students' interest in reading being as low as $40 \%$ and medium categories as much as $69 \%$. The low reading interest was due to reading awareness, low reading pleasure and reading habits.

Speaking of reading interest, Indonesia's reading interest ranking based on Central Connecticut State University (2016) ranks Indonesia $60^{\text {th }}$ out of 61 countries surveyed. Indonesia is only superior to Botswana, a former British colony located on the African Continent. Compared to neighbouring countries in Southeast Asia, Indonesia is far below Singapore which is ranked 36th, followed by Malaysia and Thailand which are ranked $53^{\text {rd }}$ and $59^{\text {th }}$ respectively. Four years earlier, in 2012, UNESCO had released data on the Indonesian reading level index of only 0.001 percent. That is, from 1,000 residents there is only one person who has an interest in reading. That is, out of every thousand Indonesians there is only one person who has an interest in reading. In 2017, the president of the Republic of Indonesia, Joko Widodo, has signed Presidential Regulation No. 87 (2017) concerning Strengthening Character Education (PPKStrengthening Character Education). KDP is to familiarize positive attitudes and behaviors at school starting from the first day of school. The Ministry of Education and develops GERNAS BAKU (National Movement for Parents Reading Books), which involves all stakeholders of educational policies, both in the internal education environment (central, provincial, city / district up to the level of the education unit) and the environment of the community and people parents to foster interest and love to read to children. But in fact this has not had a good impact on increasing reading interest in Indonesia. Previous surveys and studies have shown that the level of interest in reading in Indonesia is very low and it is a serious problem (Kartika, 2013)

The low interest in reading here shows that students dislike books, have low interest in reading and they prefer to watch television (Kartika, 2010). If offered between gadgets or books, students will prefer gadgets as a means to spend time. Both print and electronic media when discussing reading culture in Indonesia will always slip the results of a survey stating that our society is not a society that likes to read. (Al Qurtuby \& Sumanto, 2017). Seeing this situation should be of particular concern to all students and those involved in the education process in improving the quality and skills of learning. The quality and learning skills can be improved by taking time to read. So that if it continues it will get used to and create interest (Yaumi, 2014).

According to Susilowati (2016) reading is a skill that must be possessed by all education practitioners. Reading is a basic key that must be done by a student if he wants to achieve achievement in learning, because reading will add insight and knowledge. Besides reading will make a quality individual. Interest in Reading is a strong desire of individuals who are followed by efforts in the reading process (Rahim, 2008). Harris and Sippay (1980) explained that indicators of students who have high interest in reading are shown by having an awareness of the benefits of reading, attention to reading, a pleasure in reading and reading frequency.

Reading interest has a good impact and influence for students in the learning process. Based on the results of Sabriyadi, Surmana and Permana's research (2015) that there is a significant relationship between reading interest and learning achievement. Marlina and Mahdum (2017) in their research produced that there was a significant relationship between reading interest and learning outcomes. Students have an interest in reading in the teaching and learning process will quickly understand and easily remember each lesson so as to produce good learning outcomes and achievement. Interest in reading that is in students will make it more know and understand the subject matter.

It is important to foster interest in reading since elementary school because today the behavior and interest in reading has begun to weaken in the millennial era. Devi and Shanti (2004), added that at the age of 6-12 years, namely when the child enters childhood is the right time to start developing reading interest in children. At this age, children's ability to understand language in reading books develops rapidly. According to Kartono (1995), that age (7-13 years) is the age of elementary school, began to look at all events with an objective, intellectual (cognitive) and reason (moral) intertwined increasingly prominent and emotionality is reduced. So the importance of instilling interest in reading since school age so children can grow with a lot of knowledge from books read.

Interest in reading is also influenced by internal factors that originate from within myself, namely, intelligence, reading ability, attitude towards reading (Haris \& Sippay, 1980), self-concept (Denessen, Zareet \& Ecless, 2007), age, gender (Stoodt, 1996 ).Rahim (2008), explain that the factors that can influence interest in reading come from external factors, namely the family environment (focusing on the role and involvement of parents), socioeconomic and facilities in the form of libraries and the availability of reading resources (Anugra et al., 2013 ).

One internal factor that influences interest in reading is the reading self-concept (Denessen, Zareet, \& Ecless , 2007). The results of the research Melekoğlu and Wilkerson (2013) found that the concept of self-reading that will positively affect student reading behavior. This is in line with research conducted by Walgermo et al. (2018) that students who have positive self-reading concepts will have an impact on students' high reading interest. While research conducted by Viljantra et al. (2016) shows different results from previous studies that students can have positive self-reading concepts but can also have low reading interests and vice versa students can have self-concepts negative reading but have a high reading interest. In this case, the self-concept in question is the concept of self-reading which is a part or sub-area of academic self-concept. Chapman and Tunmer (1995) define the concept of self-reading is one's self-image or self-assessment in the reading process by combining the process of perception of competence in performing reading assignments, difficult or easy in the reading process and perceived attitude towards reading. self-concept of reading in students can be seen from several components, including perceptions of reading competence, perceptions of reading difficulties and attitudes towards reading.

The concept of self is formed from various impressions received by someone (Dayakisni, 2006). Self-perception of specific behaviors influences self-concepts of sub-areas (such as mathematics, social research) which will then refer to academic self-concepts. The concept of self-reading is a sub-area of academic self-concept (Marsh, 1985). Individuals who have positive self-reading concepts are shown to have competence in the reading process, a positive perception in facing reading difficulties and a positive attitude when confronted with reading activities (Chapman \& Turmer, 1995). Research conducted by Kraayenoord and Schneider (1999) states that students 'self-reading concepts are related to students' reading interests. Students who have a positive self-reading concept will also have a high interest in reading. When students have negative self-reading concepts, these students will have low interest in reading as well.

External factors that affect students' interest in reading are family environment factors by focusing on the role or involvement of parents. Sutini (2010), explains that among the various external factors of reading, the influence of the role of the family is very high contribution in influencing the formation of interests and reading skills in children. Hill and Tyson (2009) revealed the notion of parental involvement is a form of parent interaction with the school and interactions between parents and students at home in order to achieve student academic success. Parental involvement according to Hill and Tyon (2009) can be carried out through the Home-base involvement model, School-base Involvement and Academic socialization. Reading interest has a relationship with other variables. One of them interest in reading correlates with the perception of parental involvement. Hoover-Dempsey and Sandler (2005) in their study developed a model 
of parental involvement in which parental involvement in the form of monitoring, reinforcement, instruction and modeling would shape interests, self-perceptions, expectations, motivational orientation, values, achievements, children's performance. In this case students' perceptions of parental involvement have a relationship with students' reading interest so that if students' perceptions of parental involvement are positive then students will have a high interest in reading (Kimathi, 2014) Research conducted by Rahmi (2019) regarding parental involvement in increasing reading interest in children results in parental involvement having a positive and significant relationship to reading interest that if parents are positively involved in the reading process in children, children's reading interest becomes high.

Interest in reading is a study that has taken place over time and various studies have been conducted. Parental involvement is very much related to reading interest, which in this case will be assessed based on the child's perception of parental involvement. The concept of self-reading has a relationship with students' interest in reading.

\subsection{OBJECTIVES OF THE STUDY}

This study seeks to know the relationship between reading self-concept with reading interest in elementary school students; to know about the relationship between perceptions of parental involvement in education with reading interest in elementary school students; and to Know the relationship between self-concept of reading and perceptions of parental involvement in stimulant with reading interest in elementary school students.

\subsection{LITERATURE REVIEW}

\section{Reading Interest}

Interest is a feeling of liking and a sense of interest in a thing or activity. Learning with an interest will make it easier for someone to master what is being learned (Suryabrata, 2016). Ormrod (2009) defines interest as the perception that an activity raises curiosity and interest, usually accompanied by positive cognitive and affective involvement such as fun, excitement, and liking. Interests are divided into two namely situational interests and personal interests. Omrod (2008) explains in more detail that Situational interest is an interest that is temporarily triggered by something in the environment, while personal interest is an interest that is long-term and relatively stable in a topic or activity.

From some of the opinions above, it can be concluded that interest is a feeling that is more like or a sense of interest in an activity that is indicated by the desire, a tendency to pay attention to these activities without anyone asking, carried out with self-awareness and followed by feelings of pleasure. According to Tarigan (2008), reading is a process carried out and used by readers to obtain the message to be conveyed by the author through the media of words written language.

Reading Interest is a strong desire of individuals who are followed by efforts in the reading process (Rahim, 2008). Reading interest is defined as an activity in the form of encouragement in individuals in understanding word for word and the contents of a reading, with full perseverance, existence and pleasure (Dalman, 2013). Darmono (2007) states that reading interest is a strong tendency of the soul to carry out reading activities with a specific purpose Based on the description above, the writer can conclude that interest in reading is a strong desire or desire of someone who is owned by an individual followed by efforts in the reading process. Indicators of students who have high reading interest according to Harris and Sippay (1980), namely: (a). Awareness of the benefits of reading is an aspect that reveals how far subjects are aware of, know and understand the benefits of reading; (b). Attention to reading books is an aspect that expresses the attention and interest of the subject in reading books; (c) Happiness is the aspect that reveals how much the subject's pleasure towards reading activities; (d) Frequency, the aspect that reveals how often the subject is reading.

Based on the description of the theory above, it can be concluded that the reading interest is a strong desire or desire of a person that is owned by an individual followed by efforts in the reading process with awareness, attentions, happiness and frequesncy in reading.

\section{Reading Self-concept}

Reading self-concept which is a sub-area of academic self-concept. According to Chapman and Tunmer (1995) Self-concept has several sub-areas, one of which is the academic self-concept which includes the academic self-concept of reading self-concept. Chapman and Tunmer (1997) define the concept of self-reading is a picture of one's self or self-assessment in the reading process by combining the process of perception of competence in performing reading assignments, difficult or easy in the reading process and perceived attitude towards reading. Quandt and Selznick (1984) say that the concept of self-reading is a construction in an individual evidenced by a number of behaviors in reading. The concept of self-reading is the overall self-perception of oneself as a reader in reading activities (Conradi et al., 2014). Chapman et al. (2000) define the concept of self-reading as an individual's perception of reading ability in which individuals view the reading process as an important skill.

Chapman and Thumnner (1995) explain that the concept of self-reading is measured by aspects of the concept of self-reading; 1). Reading competence, which is related to referring to an individual's belief in himself in assessing his abilities and abilities in the process and task of reading; 2) Perception difficulty reading, which refers to the belief that reading activities sometimes have difficulties, or problems. This difference between perceptions is important. Because children can have positive self-perceptions about abilities while also having self-perceptions about difficulties in academic work; 3) Reading attitude refers to the affective component in reading, which is described in terms of feelings and affinity for reading (Chapman \& Tunmer, 1995).

Based on the definitions above, the author concludes that the concept of self-reading is defined as a description of one's self or selfassessment in the reading process by combining the process of perception of competence in carrying out reading tasks, difficult or easy in the reading process and perceived attitude towards reading. 


\section{Perception of Parental Involvement}

Perception is the process of organizing and interpreting stimuli in the environment in terms of individual evaluations, both positive and negative, of an object (Atkinson, Atkinson, \& Hilgard, 2000). Perception is a process that involves sensing with the receipt of stimuli by individuals (Walgito, 2010). Sabour (2013) says perception is the process of receiving, selecting, organizing, selecting, interpreting, testing, and reacting to sensory stimuli. According to Walgito (2010) objects of perception are grouped into two namely, human and nonhuman objects. Objects of human perception are called person perception or social perception, while non-human objects are called nonsocial perception or things perception.

Robbins (2003) adds that positive perception is an individual's assessment of an object or information with a positive view or in accordance with what is expected from the object perceived or from the existing rules. Meanwhile, negative perceptions are individual perceptions of certain objects or information with negative views, contrary to what is expected from the perceived object or from the existing rules.

Based on the understanding of perception according to the experts above, it can be concluded that perception is a process of organizing and interpreting an object or stimulus received both positively and negatively by individuals from the surrounding environm Hill and Tyson (2009) revealed the notion of parental involvement is a form of parent interaction with the school and interactions between parents and students at home in order to achieve student academic success. According to Grolnick and Slowiaczek (1994) explains the involvement of parents is the participation of parents through resources provided in the form of behavior, cognitive/ intellectual and personal dominant learning processes in children. Hornby (2011) defines parental involvement as a form of parental participation in the processes and educational experiences of their children.

Morrison (1988) explains that people's involvement is a process to help parents use all their abilities for their own benefit, children and the programs run by the children themselves. Parental involvement as the process of connecting parents with school programs and using program services to the best abilities of parents and school programs. (Korfmacher et al., 2008). Epstein (2005) argues that parental involvement is a form of parental responsibility for their children at home, at school and in the community which is manifested in the form of cooperation, sharing information, guiding, solving problems and achieving success.

Based on some of the explanations above, it can be concluded that the perception of parent involvement is the process of organizing, the process of interpreting and evaluating students' involvement of parents in the process of parent interaction with the school and parent interaction with students at home in order to achieve academic success. Padavick (2009), revealed that parental involvement is parental participation in education and experience in student learning both at school and elsewhere that can support student progress. Lall, Campbell and Gillborn (2004) provide an understanding of parental involvement as care behavior at home in this regard including the provision of a safe and stable environment, intellectual stimulation, discussion between parents and children and the activity of parents to participate in participation in school activities with establish good communication with the school.

The model of parental involvement according to Hill and Tyson (2009) are Home-based involvement includes strategies like communication between parents' and children about school, engagement with school work (e.g., homework help), taking children to events and places that foster academic success (i.e., museums, libraries, etc.), and creating a learning environment at home (e.g., making educational materials accessible, such as books, newspapers, educational toys). School-based involvement includes visits to school for school events (e.g., PTA meetings, open houses, etc.), participation in school governance, volunteering at school, and communication between parents and school personnel. Finally, academic socialization includes communicating parental expectations for education and its value or utility, linking schoolwork to current events, fostering educational and occupational aspirations, discussing learning strategies with children, and making preparations and plans for the future.

Based on some theoretical explanations above, it can be concluded that the perception of parent involvement is the process of organizing, the process of interpreting and evaluating students' involvement of parents in the process of parent interaction with the school and parent interaction with students at home in order to achieve academic success.

\subsection{METHODOLOGY}

\section{Research Design}

This is a quantitative correlational method. The sample used in this study was elementary school students in Yogyakarta, Indonesia. The sampling technique used in this study is purposive sampling based on certain characteristics or characteristics that are considered to have a close relationship with population characteristics, male and female students of elementary school, grade 3 , 4, and 5, ages 8-11 years, living with parents, and were able to read well. The sample in this study amounted to 47 students. Test the relationship between predictor variables with criteria (the concept of self-reading with reading interest in students or the perception of parental involvement with reading interest in students) with the product moment correlation analysis method. Whereas testing the relationship between the two predictor variables together correlates with the criterion variable (the relationship between self-concept of reading and the perception of parental involvement with reading interest in students) using the regression analysis method. Research data collection using a scale filled in online. The scale is distributed and filled out by students through google doc.

\section{Research Instruments}

This research instrument uses a scale of interest in reading compiled based on the theory of Hariss and Sippay (1980). The results of testing the validity and reliability reading interest scale resulted in 31 valid items from 32 items that were tested. The coefficient of validity moves between 0.328 to 0.684 while for testing reliability using alpha reliability, shows the reliability coefficient $(\alpha)$ of 0.925 . Reading Selfconcept scale (RSCS) that is prepared by adapting from the reading self-concept scale (RSCS) designed by Chapman and Tunmer (1995). The results of testing the validity and reliability of the RSCS scale resulted in 17 valid items from 30 items that were tested. The validity 
coefficient moves between 0.337 to 0.769 while for testing reliability using alpha reliability $(\alpha)$, shows the reliability coefficient of 0.823 . The scale of perception of parental involvement that refers to the theory of Hill and Tyson (2009). The results of testing the validity and reliability of the perception scale of parental involvement resulted in 36 valid items from 48 items tested. The coefficient of validity moves between 0.315 and 0.694 while for reliability testing uses alpha reliability, indicating a reliability coefficient $(\alpha)$ of 0.914 .

\subsection{RESULTS}

Data generated from the answers to the questionnaire on the scale of reading interest, Reading Self-concept scale and reading interest scale are used as a reference in describing the results of research by comparing hypothetical scores with empirical scores. Descriptive analysis is performed to determine the minimum, maximum, distance distribution (range), standard deviation (SD) and average (average). The results of this analysis are then used as a basis for categorizing research data. The results of the hypothetical and empirical score calculation analysis can be seen in Table 1 .

Table 1 Hypothetic description and empirical research data

\begin{tabular}{|c|c|c|c|c|c|c|c|c|}
\hline \multirow[t]{2}{*}{ Variable } & \multicolumn{4}{|c|}{ Hypothetic } & \multicolumn{4}{|c|}{ Empirical } \\
\hline & Min & Maks & Mean & SD & Min & Maks & Mean & SD \\
\hline RI & 31,0 & 124,0 & 93,0 & 15,5 & 40 & 115,00 & 90,30 & 13,1 \\
\hline RSC & 17,0 & 68,0 & 42,5 & 8,50 & 40,00 & 67,00 & 52,28 & 7,08 \\
\hline PPI & 36,0 & 114,0 & 108.0 & 24,0 & 80,00 & 136,00 & 113,15 & 13,2 \\
\hline $\begin{array}{l}\text { Inform: } \\
\text { RI } \\
\text { RSC }\end{array}$ & & $\begin{array}{l}\text { g Interes } \\
\text { g Self-cc }\end{array}$ & & & & & & \\
\hline PPI & & ion $\mathrm{Of} \mathrm{P}$ & 1 Involv & & & & & \\
\hline
\end{tabular}

After getting the results of the descriptive test, then categorizing the data of the three variables based on the norm is done. This method is done based on the assumption that the subject's score in the group is an estimate of the subject's score. The categories assigned for each scale are high, medium and low (Azwar, 2017). The data categorization formula can be seen in Table 2 below.

Table 2 Data categorization norms

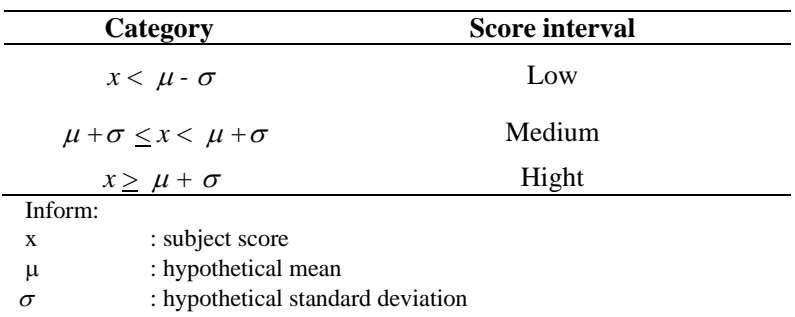

The categorization norm above is used in categorizing variables of reading interest, reading self-concept, and perceptions of parental involvement. The results of the categorization are described as follows:

Table 3 Interest reading scale score of categorization

\begin{tabular}{llccc}
\hline Criteria Variabel & Categori & Score interval & Total & \% \\
\hline Reading Interest & Low & $x<77,5$ & 3 & 6,4 \\
& Medium & $77,5 \leq x<108.5$ & 39 & 83,00 \\
& Hight & $x \geq 108,5$ & 5 & 10,6 \\
\hline & $\mathrm{N}$ & 47 & 100,0 \\
\hline
\end{tabular}

Based on Table 3, it is known that students who have low interest in reading are 3 stundents $(6.4 \%)$, the medium category is $83 \%$ (39 stundents) and the high category is $10.6 \%$ (5 stundents). It can be concluded that the variable of students' interest in reading is medium.

Table 4 Reading self-concept scale scores of categorization

\begin{tabular}{lllccc}
\hline \multicolumn{2}{c}{\begin{tabular}{c} 
Predictor \\
\multicolumn{2}{c}{ Variable }
\end{tabular}} & Categori & Interval Skor & Total & \% \\
\hline Reading & Self- & Low & $x<30,00$ & 0 & 0,0 \\
concept & Medium & $30,00 \leq x<51,00$ & 19 & 40,3 \\
& Hight & $x \geq 51,00$ & 28 & 59,7 \\
\hline & & $\mathrm{N}$ & 47 & 100,0 \\
\hline
\end{tabular}

Based on Table 4, it is known that students who have a self-concept of reading the low category are 0 students $(0.0 \%)$, the medium category is $40.3 \%$ (19 students) and the high category is $59.7 \%$ (28 students). It can be concluded that the variable self-reading concept is high. 
Table 5 Perception of parental involvement scale scores of categorization

\begin{tabular}{|c|c|c|c|c|}
\hline $\begin{array}{c}\text { Predictor } \\
\text { Variable }\end{array}$ & Category & Interval Skor & Jumlah & Persentase \\
\hline \multirow{4}{*}{$\begin{array}{ll}\text { Perception } & \text { of } \\
\text { parental } & \\
\text { involvement } & \\
\end{array}$} & Low & $x<84,00$ & 0 & 0,0 \\
\hline & Medium & $84,00 \leq x<132,00$ & 44 & 93,0 \\
\hline & Hight & $x \geq 132,00$ & 3 & 6,4 \\
\hline & & $\mathrm{N}$ & 47 & 100,0 \\
\hline
\end{tabular}

Based on Table 5, it is known that students who get the perception of parental involvement in education in the low category are 0 students $(0.0 \%)$, the medium category is $93 \%$ (44 students) and the high category is $6,4 \%$ ( 3 students). It can be concluded that the variable perception of parental involvement in education is medium. Furthermore, the explanation of data categorization is also explained or presented in the form of a graph below:

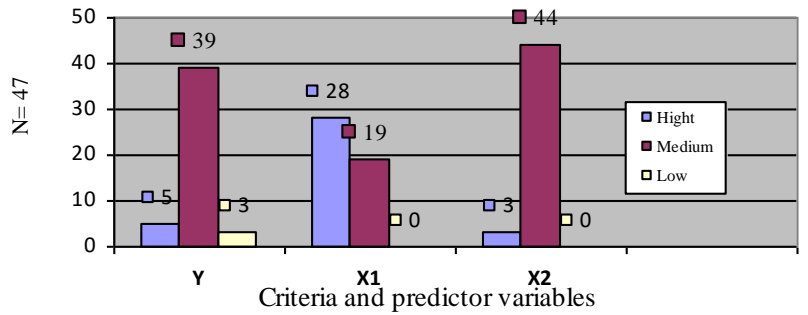

Figure 1 Variable score categorization graph

From figure 1 above, it was concluded that of the 47 students, the majority of students had a medium level of interest in reading of 39 or $83 \%$, reading self-concept with a high category of 28 or $59.7 \%$ and the perception of parental involvement in the medium category of 44 or $93 \%$. so it can be concluded that the majority of students are in the medium category for the variable reading interest and the perception of parental involvement and the high category for the variable self-concept reading.

Table 6 Normality of test

\begin{tabular}{lccccc}
\hline \multicolumn{1}{c}{ Variable } & \multicolumn{1}{c}{$\begin{array}{c}\text { Kolmogorov- } \\
\text { Smirnov } \\
\mathbf{Z}\end{array}$} & $\mathbf{p}$ & Respondents & Result \\
\hline Reading Interest & 0,117 & 0,109 & 47 & Normal \\
Reading Self-concept & Parental & 0,096 & 0,321 & 47 & Normal \\
Perception of & 0,087 & 0,200 & 47 & Normal \\
Involvement & & & & \\
\hline
\end{tabular}

Base on Table 6, the reading interest normality test obtained a KSZ value of 0.117 and a p value of 0.109 (p>0.05). This shows that the variable interest in reading in students has a normal distribution. 2) Normality test of self concept reading data obtained KSZ value of 0.096 and $p$ value of 0.321 ( $p>0.05$ ). This shows that the variable self-concept of reading in students has a normal distribution. 3 ) Normality test data on the perception of parental involvement in education obtained K-S-Z value of 0.087 and $p$ value of 0.200 ( $p>0.05$ ). This shows that the variable perception of parental involvement in students has a normal distribution.

Table 7 Linearity of test

\begin{tabular}{llccc}
\hline \multirow{2}{*}{ Criteria } & \multirow{2}{*}{ Predictors } & \multicolumn{2}{c}{ Score } & \multirow{2}{*}{ Result } \\
\cline { 3 - 4 } Reading Interest & Reading Self-Concept & F & $\mathbf{p}$ & \\
& Perception of Parental Involvement & 76,554 & 0,000 & Linier \\
& & 72,590 & 0,000 & Linier \\
\hline
\end{tabular}

Based on table 7 the linearity test results in the above table, the following results are obtained: 1) Variable of interest in reading has a $\mathrm{F}$ value of 36.554 with significance in linearity $(\mathrm{p}<0.05)$, so it can be concluded that between the variable self-concept of reading and reading interest there is a linear relationship. 2). Variable Perception of parental involvement in education $F$ value of 72.590 with significance in linearity $(\mathrm{p}<0.05$ ), so it can be concluded that between the variables of perception of parental involvement and reading interest there is a linear relationship. 
Table 8 Product moment correlation of analysis

\begin{tabular}{ccccc}
\hline Criteria & Predictors & $\begin{array}{c}\text { Product Moment } \\
\text { value }\end{array}$ & $\begin{array}{c}\text { Sig (2 } \\
\text { tailed) }\end{array}$ & Result \\
\hline Reading Interest & $\begin{array}{c}\text { Reading Self-Concept } \\
\text { Perception of Parental } \\
\text { Involvement }\end{array}$ & 0,652 & 0,000 & Significant \\
& 0,697 & 0,000 & Significant \\
\hline
\end{tabular}

Based on table 8, the product moment correlation analysis results the following results are obtained: Variable reading self-concept has a positive and significant relationship to students' interest in reading $(\mathrm{p}<0.01)$. The value of $\mathrm{r}=0.652$, if it is squared $\left(\mathrm{r}^{2}\right)$ it becomes 0.425 . This means that there is a positive relationship between the concept of self-reading and reading interest which means that the more positive the concept of self-reading, the higher the interest in reading. The coefficient of determination $\left(\mathrm{r}^{2}\right)$ of 0.425 means that reading self-concept contributes effectively to students' reading interest of $42.5 \%$ while the remaining $57.5 \%$ is influenced by other variables.

Variable perception of parental involvement has a positive and significant relationship to students' interest in reading ( $p<0.01$ ). The value of $r=0.697$, if it is squared $\left(r^{2}\right)$ becomes 0.845 , which means there is a positive relationship between the perception of parental involvement with the reading interest of students that the more positive perception parental involvement, the higher interest in reading. The effective contribution of perceptions of parental involvement in education about reading interest in students is $\left(r^{2}\right)=48.6 \%$ while $51.4 \%$ was determined by other variables not measured in this study.

Table 9 Multiple linear regression analysis

\begin{tabular}{cccc}
\hline Multiple correlation value (R) & F & P & Result \\
\hline 0,690 & 28,383 & 0,000 & Significant \\
\hline
\end{tabular}

Based on table 9, about the regression test found the value of $F$ of 28.383 and $p=0.000(p<0.01)$, can be concluded that the variable reading self-concept and perception of parental involvement stimulants have a relationship to student reading interest. The value of $r=0.690$ when squared $\left(r^{2}\right)$ becomes 0.563 . The coefficient of determination $\left(r^{2}\right)$ of 0.563 means that the effective contribution of the variable self-concept of reading and perception of parental involvement in stimulant to student motivation is $56.3 \%$ while the remaining $43.7 \%$ is influenced by other variables not included in this study.

\subsection{DISCUSSION}

Based on the results of data analysis and hypothesis analysis testing in this study, it was found that; there is a positive relationship between self-concept of reading with interest in reading; there is a positive relationship between the perception of parental involvement with interest in reading; and there is a relationship between self-concept of reading and perception of parental stimulant involvement with interest in reading, which is described as follows:

\section{The Relationship between Reading Self-Concept with Reading Interest}

Based on the results of the analysis of hypothesis testing using product moment correlation techniques showed a correlation number of 0.652 ( $p<0.01$ ). The concept of self-reading contributes effectively to students' interest in reading by $42.5 \%$ while the remaining $57.5 \%$ is influenced by other variables, among others. there is a positive relationship between the self-reading concept and reading interest, this means that the more positive the self-concept of reading, the higher the students' interest in reading. Chapman \& Tunmer (1995) explained that the individual's self-reading concept had a positive impact on increasing students' reading interest, because the individual would assess the reading process he did himself, the more positive the self-concept of reading owned by an individual would increase reading interest and motivation in children.

This is supported by the results of previous studies conducted by Walgermo et al. (2018) that having a self-concept of reading has a positive relationship with reading interest. The research by Denessen et al. (2007), explains that there is a positive relationship between the concept of self-reading and reading interest. The results of previous studies reinforce the results of this study because it shows consistent results that there is a relationship between the concept of self-reading and reading interest, which means the concept of self-reading is really a factor that is significantly related to interest in reading.

Individuals who have positive self-reading concepts are shown to have competence in the reading process, a positive perception in facing reading difficulties and a positive attitude when confronted with reading activities (Chapman \& Turner, 1995). Research conducted by Kraayenoord and Schneider (1999) states that students 'self-reading concepts are related to students' reading interests. Students who have a positive self-reading concept will also have a high interest in reading. When students have a negative self-reading concept, then these students will have low interest in reading as well.

Students who have positive self-reading concepts will encourage high interest and motivation to read, because self-reading concepts as a self-assessment of how much reading ability, perceptions of reading difficulties and attitudes in reading. If each component is positively owned and assessed by the individual, the individual will be increasingly challenged and motivated to continue reading books, in this case the interest in reading will increase because the individual has a positive self-concept (Chapman \& Turner, 1995)

The concept of self-reading is also a factor for a student to be happy or not in reading activities. The attitude of reading has to do with aspects of pleasure in reading interest. Smith (1991) explains that the attitude in reading can be seen from the readiness of students in the form of likes or dislikes when reading activities. Positive attitudes in reading will have an influence on students' enjoyment and fondness of reading, that is, pleasant feelings in reading that a positive attitude in reading activities will increase the intensity of feelings or high enjoyment in reading. Ajzen and Fishbein (1980) adds attitudes as learning dispositions about how to behave, whether negative or positive 
and reading attitudes refer to a person's nature of reading as an activity that gives rise to pleasure while reading. So that a positive reading attitude can inspire a positive reading experience that has implications for the feeling of being happy every time you read a book. The results of this study have proven that the concept of self-reading is related to interest in reading.

Students have positive self-reading concepts so students must have a positive reading attitude towards reading activities. reading attitude is one aspect of self-concept reading. A positive attitude towards reading will encourage attitudes into reading behavior, have a high interest in reading and improve reading skills. Students who enjoy reading will more often do reading activities. This activity increases knowledge and experience in reading texts and ultimately improves reading comprehension (Mullis et al., 2003). Some research shows that teachers can influence positive attitudes towards reading with various interventions specifically or in general through learning models that demonstrate skills and comfort in reading. This is related to the positive attitude shown to students (Martinez \& Aricak, 2008). The learning process and reading environment factors that can be created as an ideal atmosphere and based on a positive attitude towards reading, will encourage the activeness of reading in students. Situations that encourage reading will direct aspects of students' affection and cognition for reading. This appears in incorporation of aspects of student focus on reading and a strong curiosity in students (Guthrie et al., 2006). On the variable concept of self-concept reading, especially on aspects of reading competance, the experience of student learning success or failure to learn to read has an affect on students. Attitudes toward reading and other psychological aspects that cause success or failure in learning can cause more enthusiasm or the opposite can cause frustration in students (Beech \& Singlenton, 1997). So the realm of affection such as aspects of attitude towards reading which is a component of the concept of self-reading must be a serious concern in the process of learning to read to students so that their attitudes and commitment in learning are maintained read and read to study.

One aspect that needs to be improved in the concept of self-reading is the aspect of perception of reading difficulties. This refers to the belief that reading activities have a level of difficulty. So that the child's perception of him in reading difficulties will be a motivation for children to deal with reading difficulties so that children continue to read over and over to understand the purpose of reading. This relates to the aspect of frequency in reading. So that it will also bring attention or attention to children in reading. Every child has different perceptions of reading difficulties, because children can hold positive and negative self-perceptions about reading difficulties (Nicholls \& Miller, 1984). Tonessen (2011) in his research that high reading skills have a positive impact on reading interest. one aspect of self-concept reading is reading competance. Reading skills play cognitive processes in terms of spelling, translating each word or sentence that is read, as well as the meaning of a reading. this means that the individual views himself as an individual whose self-concept reads positively which can then have an impact on high reading interest. Bandura (1995) added that to make individuals have a good self-concept in carrying out learning tasks one of which is reading, children must have a high level of self-confidence that children are able to deal with difficulties in the learning process. children are confident that they are able and able to become good readers of books, when children are confident that they can overcome this difficulty then they will succeed in the reading process and have reading achievement. confidence and self-confidence that children are able to complete difficult reading assignments are part of the perceptual aspects of reading difficulties in self-reading concepts.

A positive self -concept of reading that students have will make students have a positive image of themselves in doing reading activities both at home, school and in leisure time, this shows that students have a sense of fun in reading books done with pleasure and not forced in doing reading activities where with a positive self -concept of reading makes students more and more continue to have interest, motivation and reading ability that will be much better in the future.(Barton et al., 2020). So in accordance with the findings of this study and studies that support that it is very important for students to develop positive self-concepts of monat reading, because positive selfconcepts will increase students' interest in reading.

\section{The Relationship between Perception of Parental Involvement with Reading Interest}

The results of testing the data using the product moment correlation analysis technique showed that the correlation value obtained was 0.697 ( $\mathrm{p}<0.01$ ), this means that there was found a positive relationship between the perception of parental involvement with interest in reading, that the more positive perception of parental involvement in education, the higher the student's interest in reading. The finding in this study is that the effective contribution of the perception of parental involvement in education with students' reading interest is $48.6 \%$ while the remaining $51.4 \%$ is influenced by other variables not examined by researchers.

Previous research conducted by Rahmi (2019) regarding parental involvement in increasing reading interest in children results in parental involvement having a positive and significant relationship to reading interest in children that if parents are positively involved in the reading process in children, reading interest the child becomes tall. Research Hoover et al. (2005) in their study developed a model of parental involvement in which parental involvement in the form of monitoring, reinforcement, instruction and modeling would shape interests, self-perceptions, expectations, motivational orientation, values, achievements, children's performance. In this case students' perceptions of parental involvement have a relationship with students' reading interest so that if students' perceptions of parental involvement are positive then students will have a high interest in reading.

Parental involvement has a relationship with reading interest in students. In this case student perception plays an important role in perceiving parents involvement in reading activities. This is evidenced through research conducted by Fakhriyah (2018) that there is a positive relationship between the perception of parental involvement with reading interest in elementary school students. This is in line with the results of Klauda's research (2007) regarding students' perceptions of the involvement of parents and friends in reading that are related to motivation and reading habits. In this case students' perceptions of parental involvement have a relationship with student interests so that when students' perceptions of people's involvement positive parents then students will have high interest. The more positive the student's perception of parental involvement, the higher the student's interest in reading. In line with the above research, research conducted by Kitmachi (2014) with the title the role of parental involvement in the reading process in children shows that parents who are involved in the family environment in the child's learning process, especially in reading, affect children's reading motivation and reading skills related to interest. The results of this study have proven that the perception of parental involvement in education is significantly related to students' interest in reading. This finding is in line with Williams et al. (2002), in their research explaining that the involvement of positive and high parents who have responsibility for children's success in the reading process. parents believe that children's success in the process of learning and reading is not only the role of the teacher but the involvement of parents is also important in fostering motivation and interest in reading in children. 
Students have a positive attitude towards reading both at school and at home when students feel that parents are involved in the learning process at home and participate in school. When children are at the elementary school level, parental involvement is still important in improving the learning process, one of which is reading, and achievement, things parents can do is collaborate with the school ie the teacher in monitoring the child's learning development that is related to progress and obstacles in children during school. Parents involved can offer additional resources to help children's learning, one of which is in the reading process. (Ingram, Wolfe \& Lieberman, 2007). Parents play a very effective role in instilling and accustoming reading behavior to their children because parents are the first and foremost force to increase and stimulate the potential for learning to develop consistent reading habits, learning stimuli that parents provide to children in reading book activities, it will be very beneficial for the development of children's learning, especially in the process of reading books which aim to increase children's preferences for reading behavior (Ahmad et al., 2020).

Grolnick (1994) found that parental involvement felt positively by children will affect learning achievement because of encouragement, motivation, interest. Parental involvement will stimulate children to practice reading, thus increasing their reading skills. Holdaway, (1979) explained that parents were the models of readers for children. parents act as positive examples that children try to emulate. As such, children will try to read on their own and when parents strengthen these efforts, children's reading skills improve significantly. Child's interest in reading and enthusiasm in reading books is influenced by parents' reading behavior at home. when parents read at home with children the child will have the interest and motivation to try reading the available reading material on their own. As a result, children practice their own reading thus significantly increasing their interest and reading skills. parents can get involved with creating a home environment like a reading book. A literacy-rich home environment positively influences children's achievement, motivation and interest in reading. Epstein (2005); Maduekwe and Adeosun (2010) found that home environments that have a lot of reading material correlate strongly with achievement, motivation, interest and reading skills of children in school. so the need for parents to provide facilities that support and stimulate children to read. This finding is in line with the opinion of Morrow and Young (1997) which states that the reading activities between children and their parents influence the children's attitudes and interests in reading.reading programs between parents and children, children become like to spend their free time with reading activities (Sandjaja, 2001). when parents read books for children will familiarize them and stimulate the children's dynamics to be interested and get a good reading experience. at the elementary school level, for example, starting with reading books to children about story books and general knowledge books. (Zhou \& Yadav, 2017).

This is also supported by Sobel's (2017) study that children will be more easily interested in reading and interest in learning if parents are actively involved in the process. Furthermore, research conducted by Mwanda et al. (2016), states that students or children will be more trusting and comfortable when learning if accompanied by parents. When parents take the time to be involved in the process of reading with children, children become more interested in reading. reading makes them want to explore things written in books as they grow older, thus fostering a culture of reading that is accustomed to from an early age. The attitude and involvement of parents towards their children's learning positively influences motivation, interest and reading performance regardless. When parents read to their children, the opportunity to interact positively with children and create a pleasant reading experience. The quality of parental involvement in terms of effective interactions in growing interest in reading is very important for children. (Mwangi, 2018).

Mulyani (1978) argues that the level of development of someone who is most beneficial for the development of interest in reading is in the sensitive period, which is around the age of 5 to 6 years. Then this interest in reading will develop into adolescence. The interest in reading must first be instilled through education and family habits during this sensitive period. Children aged 5 to 6 years love listening to stories. At first they were interested not in the content of the story, but in the enjoyment gained in their proximity to their parents. When sitting together or sitting on a parent's lap, the child feels love and tenderness. A pleasant and supported atmosphere by a story book full of beautiful pictures will make children become interested and happy to enjoy the story from the book. Through the process of imitation, children will love to imitate the activities of reading stories done by their parents. This imitation will be repeated if the child also often sees parents doing reading activities. Children will imitate the style and behavior of parents in reading. Then after the child is able to read on his own, then childrens would love to practice his reading skills by reading his own books available at home. The willingness to read books on their own initiative is the beginning of growing interest in children's reading. The next development of interest in reading is influenced by several factors. (Yetti, 2009).

So it can be seen that interest in reading is greatly influenced by parental involvement, therefore interest in reading needs to be instilled and nurtured since the child was a child. The family is the earliest and dominant environment in instilling, fostering and fostering children's reading interest. Parents need to instil awareness of the importance of reading in children's lives, after that only educators in schools, peers and the community.

\section{The Relationship between Reading Self-concept and Perception of Parental Involvement with Reading Interest}

Based on the results of the regression analysis test showed that the concept of self-reading and the perception of parental involvement in were significantly related to students' interest in reading. The results of multiple regression tests found the value of $r$ was 0.697 with $R$ square $=0.563, \mathrm{~F}$ value $=28.383(\mathrm{p}<0.01)$. These results indicate that the concept of self-reading and the perception of parental involvement are factors that play a role in the formation of elementary school student interest. Based on the results of the analysis, it is known that the effective contribution of self-concept of reading and perception of parental involvement on reading interest is $56.3 \%$, while the remaining $43.7 \%$ is influenced by other factors not examined in the lesson.

Interest in Reading is a strong desire owned by individuals who are followed by efforts in the reading process (Rahim, 2008). Chapman and Thumnner (1995) explain that the concept of positive self-reading possessed by individuals makes individuals have positive judgments about themselves related to the reading activities carried out. Individuals who consider reading as a positive activity that has a good impact on themselves in terms of reading. Conversely, individuals who have a negative self-reading concept will see themselves as not having the ability and good reading skills so that there is a tendency to avoid any activities related to reading. Mokoagow (2016) explains that high reading interest will be able to absorb various information and knowledge. High reading ability and interest are the basic capital for student success in various subjects and advancement in education. The family environment is a determining factor for children in developing their interest activities, one of which is asking for early reading. The family environment can shape the personality, attitudes, values, and abilities of individual languages. Conditions at home affect personal and individual adjustment in society. This condition can in 
turn help individuals, and can also prevent individuals from reading. Individuals who live in a harmonious household, a house full of love, whose parents understand their children, and prepare an individual with high self-esteem, will not find significant obstacles in reading. This means that parents are involved in the reading process of children at home.(Hurlock, 2011). The findings in this study are supported by research by Xia, Gu and $\mathrm{Li} \mathrm{(2019)} \mathrm{that} \mathrm{high} \mathrm{reading} \mathrm{interest} \mathrm{can} \mathrm{be} \mathrm{achieved} \mathrm{and} \mathrm{influenced} \mathrm{by} \mathrm{self-concept} \mathrm{of} \mathrm{reading} \mathrm{and} \mathrm{the} \mathrm{role} \mathrm{of}$ parental involvement in stimulating children in increasing reading interest and motivation in children. When the child has a positive selfconcept of reading followed by the role of the parent that the child feels positively, then the interest and motivation to carry out reading activities is high.

So with this finding that with the positive reading self- concept and the perception of positive parental involvement felt by students or children will make a high contribution to increasing reading interest of students in the millennial era

Overall the variables of self-concept of reading and the perception of parent involvement are both important factors in the realization of interest in reading in students.

\subsection{CONCLUSION}

Based on the discussion above, it can be concluded that, there is a positive relationship between reading self-concept and reading interest, which means that the more positive the self-concept of reading, the higher the interest in reading students, conversely the more negative the concept of self-reading, the lower the interest in reading students; there is a positive relationship between the perception of parental involvement with reading interest in students that the more positive the student's perception of parental involvement, the higher the interest in reading, conversely the more negative the student's perception of parental involvement, the lower the interest in reading; and there is a relationship between reading self-concept and perception of parental involvement in stimulant with reading interest, meaning that students who have a positive self-reading concept and are supported by positive parental involvement have succeeded in increasing students' reading interest in the millennial era. The level of reading interest possessed by students is in the medium category, the concept of selfreading is in the high category and the perception of parental involvement is at the medium level.

\subsection{LIMITATIONS}

This study only examined two predictor variables. For further researchers who wish to research reading interest, it is advisable to look at other factors as predictors that influence students' interest in reading and further researchers can use a larger sample. In this study, one of the findings in this study is that predictors of parental involvement have a positive relationship with reading interest, for subsequent researchers who wish to examine reading interest, it is recommended to examine more specifically about father's involvement and mother's involvement with reading interest, because the variables researched is still general in nature so it needs to be specified again.

\section{References}

Ahmad, Z., Tariq, M., Chaudhry, M.S., \& Ramzan, M. (2020). Parent's Role In Promoting Reading Habits Among Children: An Empirical Examination. Library Philosophy and Practice, 1-21.

Ajzen, I., \& Fishbein, M. (1980). Understanding Attitudes and Predicting Social Behavior. Englewood Cliffs, NJ: Prentice-Hall

Al Qurtuby, \& Sumanto. (2017). Meningkatkan Budaya Baca dan Literasi Masyarakat Indonesia. Diperoleh melalui http://www.liputan6.com/news/read/3203062/meningkatkan-budaya-baca-dan-literasi-masyarakatindonesia, pada tanggal 14 Januari 2020.

Antari, D.N., Sundari, N., \& Wulan, N.S. (2016). Studi Deskriptif Minat Baca Siswa Sekolah Dasar Kelas V Di Kota Serang. Antologi UPI, 4(2).

Anugra, H., Yusup, P.M., \& Erwina, W. (2013). Faktor-Faktor Dominan Yang Mempengaruhi Minat Baca Mahasiswa Survei Eksplanatori Tentang Minat Baca Mahasiswa di UPT Perpustakaan ITB. Jurnal Kajian Informasi \& Perpustakaan, 1(2), 137-146.

Atkinson, R.L., Atkinson, R.C., \& Hilgard, E.R. (2000). Introduction to Psychology. San Diego: Harcourt Brace Jovanovich, Publishers

Azwar, S. (2017). Dasar-dasar Psikometrika. Yogyakarta: Pustaka Pelajar

Bandura, A. (1995). Self-Efficacy in Changing Societies. Cambridge: Cambridge University Press.

Bangsawan, I.R. (2018). Minat Baca Siswa. Sumatera Selatan: Dinas Pendidikan, Pemuda Olahraga dan Pariwsata.

Barton, G.M., Armstrong, R.M., \& Westerveld, M.F. (2020). Reading Self-Concept and Student Perceptions. In Reading Success in the Primary Years, 77-88. Springer, Singapore

Beech, J.R., \& Singlenton, C. (1997). The Psychological Assesment of Reading. London: Routledge

Bensoussan, M. (1998). Schema Effects in EFL Reading Comprehension. Journal of Research in Reading, 21(3), $213-227$.

Central Connecticut State University. (2016). World's Most Literate Nations Ranked. Diperoleh melalui https://webcapp.ccsu.edu/?news=1767\&data pada tanggal 14 Januari 2020.

Chapman, J.W., \& Tunmer, W.E. (1995). Development Of Young Children's Reading Self-Concepts: An Examination of Emerging Subcomponents and Their Relationship with Reading Achievement. Journal of Educational Psychology, 87(1), 154.

Chapman, J.W., Tunmer, W.E., \& Prochnow, J.E. (2000). Early Reading-Related Skills and Performance, Reading Self-Concept, and the Development of Academic Self-Concept: A Longitudinal Study. Journal of Educational Psychology, 92(4), 703-708.

Chen, S., Sun, H., Zhu, X., \& Chen, A. (2014). Relationship Between Motivation and Learning in Physical Education And After-School Physical Activity. Research Quarterly for Exercise and Sport, 85(4), 468-477.

Conradi, K., Jang, B.G., \& McKenna, M.C. (2014). Motivation Terminology in Reading Research: A Conceptual Review. Educational Psychology Review, 26(1), $127-164$.

Cotton, K. \& Wikelund, K. (1987). Parent Involvement in Education. United States: Office of Educational Research and Improvement (OERI).

Dalman, H. (2013). Ketrampilan Membaca. Jakarta: PT. Raja Grafindo Persada.

Darmono, (2007). Perpustakaan Sekolah: Pendekatan Aspek Manajemen dan Tata Kerja. Jakarta: Grasindo.

Dayakisni, T. (2006). Psikologi Sosial. Malang: UMM Press.

Denessen, J.J.A., Zarrett, N.R., \& Ecless, J.S. (2007). I Like To Do It, I'm Able, And I Know I Am: Longitudinal Couplings Between Domain-Specific Achievement, Self-Concept, and Interest. Child Development, 78(2), 430-447.

Epstein, J.L. (2005). School-Initiated Family and Community Partnerships: This We Believe in Action. Implementing Successful Middle Level Schools, 77-96.

Epstein, J.L., \& Salinas, K.C. (2005). Partnering With Families and Communities. Journal Educational Leadership, 61(8), 12-18. 
Fakhriyah, D.S. (2018). Peran Persepsi Keterlibatan Ayah dan Keterlibatan Ibu Serta Konsep Diri Membaca Terhadap Minat Baca Siswa Sekolah Dasar. (Master's thesis, Fakultas Psikologi Universitas Gadjah Mada).

Kimathi, H.K. (2014). Parental Involvement in Primary Standard Three Pupils' Reading at Home in Igembe South Constituency, Meru County, Kenya. (Unpublished master's thesis). Kenyatta University.

Klauda, S.L.L. (2007). The Relations of Children Perceived Support for Recreational Reading from Parents and Friends to Their Motivation for Reading. (Unpublished doctoral dissertation). Faculty of the Graduate School of the University of Maryland.

Guthrie, J.T., Wigfield, A., Humenick, N.M., Perencevich, K.C., Taboada, A., Barbosa, P., Davis, M.H., Scafiddi, N.T., \& Tonks, S. (2006). Increasing Reading Comprehension and Engagement Through Concept-Oriented Reading Instruction. Journal of Educational Psychologogy, 96(3), 403-423.

Grolnick, W.S., \& Slowiaczek, M.L. (1994). Parents' Involvement in Children's Schooling: Multidimensional Conceptualization And Motivational Model. Child development, 65(1), 237-252.

Hill, N. E., \& Tyson, D. F. (2009). Parental Involvement in Middle School: A Meta-Analytic Assessment Of The Strategies That Promote Achievement. Developmental Psychology, 45(3), 740.

Harris A.J \& Sipay, E.R. (1980). How To in Increase Reading Ability: A Guide to Development and Remedial Methods. New York: Longman.

Humas. (2016). 91,68 Persen Penduduk Indonesia Lebih Suka Menonton TV. Kulonprogokab. Retrieved From www.kulonprogokab.go.id: www.kulonprogokab.go.id/v21/91-68-Persen-Penduduk-Indonesia-Lebih-Suka-Menonton-Tv-daripada-Membaca_4201 (Diakses 26 Oktober 2016)

Holdaway, D. (1979). The Foundations of Literacy. Sydney: Ashton Scholastic.

Hoover-Dempsey \& Sandler. (2005). Final Performance Report for OERI Grant \# R305T010673: The Social Context of Parental Involvement: A Path to Enhance Achievement. Project Monitor. Department of Psychology \& Human Development. Vanderbilt University.

Hornby, G. (2011). Parental Involvement in Childhood Education: Building Effective School-Family Partnerships: Springer Science \& Business Media.

Hurlock, E.B. (2011). Psikologi Perkembangan: Suatu Perkembangan Sepanjang Rentan Kehidupan. Jakarta: Erlangga.

Ingram, M., Wolfe, R.B., \& Lieberman, J.M. (2007). The Role of Parents in High-Achieving Schools Serving Low-Income, At-Risk Populations. Journal Of Education and Urban Society, 39(4), 479-497.

Kartika, E. (2010). Memacu Minat Membaca Siswa Sekolah Dasar. Jurnal Pendidikan Penabur, 3(8), 113-128.

Kimathi, H.K. (2014). Parental Involvement in Primary Standard Three Pupils' Reading at Home in Igembe South Constituency, Meru County, Kenya. (Master's thesis). Kenyatta University.

Kementerian Pendidikan dan Kebudayaan Republik Indonesia (2018). Seri Pendidikan Orang Tua: Menumbuhkan Minat Baca Anak [Parental Education SeriesFosteringchildren's Interest In Reading]. Jakarta: Direktorat Pembinaan PendidikanKeluarga, Direktorat Jenderal Pendidikan Anak Usia Dini dan Pendidikan Masyarakat.

Lall, M.C., Campbell, C., \& Gillborn, D. (2004). Parental Involvement in Education. Sheffield Hallam University. Educational Policy Research unit.

Maduekwe, A.N., \& Adeosun, A.O. (2010). Parents and Their Children's Literacy Development: Improvement Strategies. Nigeria: University of Lagos.

Marlina, L., Caska, C., \& Mahdum, M. (2017). Hubungan Minat Baca Dan Motivasi Belajar Dengan Hasil Belajar Ekonomi Siswa Kelas XI IPS Sman 10 Pekanbaru. Jurnal Pendidikan Ekonomi dan Bisnis, 9(1), 33-47.

Marsh, H.W. (1985). Age And Gender Effect in Physical Self Concept For Adolescent Elite Athlete And Nonatheletes : A Multicohort-Multioccasion Design. Journal of Sport and Exercise Psychology, 20, 277-259.

Martinez, R., Aricak, O.T., \& Jewell, J. (2008). Influence of Reading Attitude on Reading Achievement: A Test Of Temporal-Interaction Model. Psychology in the Schools, 45(10), 1010-1022

Mullis, I.V., Martin, M.O., \& Gonzalez, E.J. (2003). PIRLS 2001 International Report. Boston: International Study Center.

Mulyani, A.N. (1981). Pembinaan Minat Baca dan Promosi Perpustakaan. Berita Perpustakaan Sekolah, I, 24-29.

Melekoğlu, M.A. \& Wilkerson, K.L. (2013). Motivation To Read: How Does It Change For Struggling Readers With And Without Disabilities? International Journal of Instructions, 6(1): 77-88.

Morrow, L.M., and Young, J. (1997). A Family Literacy Program Connecting School and Home: Effects On Attitude, Motivation And Literacy Achievement. Journal of Educational Psychology, 89(4), 736 - 742.

Morrison, G.S. (1988). Education And Development of Infants, Todlers and Preschoolers. USA: Scott, Foresman.

Mwanda, G.M., Odundo, P., Midigo, R., \& Mwanda, O.S. (2016). Adoption of the Constructivist Learning Approach in Secondary Schools in Kenya: Focus on Learner Achievement in Biology by Class Category. US-China Education Review, 6(1), 31-44.

Mwangi, J. (2018). Parental Involvement in Reading: Does Involvement Translate to Performance in Kiswahili Comprehension Among Elementary School Pupils in Kenya? International Journal of Scientific and Education Research, 2(2), 67-84.

Nicholls, J.G., Miller, A.T., \& Nicholls, J.G. (1984). Development and its Discontents: The Differentiation of the Concept of Ability the Development of Achievement Motivation. CT JAI Press, 185(1), 218-223.

Noviriani, Lukman, S., Bakti, U., \& Indah, P. (2019). Indeks Literasi Membaca 34 Provinsi. Diakses melalui http://repositori.kemdikbud.go.id/13033/1/Puslitjakdikbud_Indeks\%20Aktivitas\%20Literasi\%20Membaca\%2034\%20Provins pada tanggal 16 Januar 2020.

Nursalina, A.I., \& Budiningsih, T.E. (2014). Hubungan Motivasi Berprestasi Dengan Minat Membaca Pada Anak. Educational Psychology Journal, 3(1), 1-7.

Ormrod, J.E. (2008). Psikologi Pendidikan: Membantu Siswa Tumbuh dan. Berkembang Jilid II. (A. Kumara, Penerj.) Jakarta: Penerbit Erlangga.

Padavick, J.F. (2009). Parental Involvement with Learning And Increased Student Achievement. (Doctoral dissertation). Walden University.

Paud-dikmas Kemendikbud. (2016) Retrieved from: www.paud-dikmas.kemendikbud.go.id https://www.paud-dikmas.kemdikbud.go.id/bindikmas/berita/gerakanindonesia-membaca-menumbuhkan-budaya-membaca. Diakses 18 Oktober 2019.

Quandt, I., \& Selznick, R. (1984). Self-Concept And Reading. International Reading Association.

Rachman, M.A., Rachman, Y.B., \& Rachmawati, Y.M. (2018). Minat Baca Siswa Sekolah Dasar Di Depok: Studi Kasus Di SDN Anyelir 1 Depok Jaya. Jurnal Ilmu Informasi, Perpustakaan, Dan Kearsipan, 19(2), 1-8

Rahim, F. A. (2008). Pengajaran Membaca di Sekolah Dasar. Jakarta: Bumi Aksa.

Rahmi, R. (2019, May). Parental Involvement to Increase Children's Reading Interest For Preschool Children's Character Development. International Conference on Early Childhood Education, 435-444.

Robbins, S.P. (2002). Perilaku Organisasi. Edisi Sembilan, Jilid 2. Edisi Bahasa Indonesia. Jakarta: PT Indeks Kelompok Gramedia

Sabriyadi, S., Sumarna, N., \& Permana, T. (2015). Hubungan Antara Minat Baca Dengan Prestasi Belajar Pada Mata Pelajaran Produktif di SMK. Journal of Mechanical Engineering Education, 2(1), 124-129.

Sobur, A. (2013). Psikologi Umum. Cetakan kelima. Jakarta: Pustaka Setia

Sobel, D. (2017). Outdoor School for All: Reconnecting Children to Nature. In Earth (Ed.), 23-33. Island Press, Washington, DC

Sandjaja, S. (2001). Pengaruh Keterlibatan Orang Tua Terhadap Minat Membaca Anak Ditinjau Dari Pendekatan Stres Lingkungan. Psikodimensia Kajian Ilmiah Psikologi, 2(1), 17-25.

Suryabrata, S. (2016). Psikologi Pendidikan. Jakarta: Raja Grafindo Persada.

Sutini. (2010). Upaya Meningkatkan Minat Baca Siswa Kelas III Sekolah Dasar. Jurnal Pendidikan Interaksi, 5(5), 56-64.

Tarigan, H.G. (2008). Membaca Sebagai Suatu Keterampilan Berbahasa. Bandung: Aksara.

Tonnessen, F. E. (2011). What Are Skills? Some Fundamental Reflections. L1 - Educational Studies in Language and Literature, 11(1), 149-158.

Viljaranta, J., Kiuru, N., Lerkkanen, M.K., Silinskas, G., Poikkeus, A.M., \& Nurmi, J.E. (2017). Patterns Of Word Reading Skill, Interest and Selfconcept of Ability. An International Journal of Experimental Educational Psychology, 37(6), 712-732.

Walgermo, B.R., Foldnes, N., Uppstad, P.H., \& Solheim, O.J. (2018). Developmental Dynamics of Early Reading Skill, Literacy Interest And Readers' Self-Concept Within The First Year Of Formal Schooling. Reading and Writing, 31(6), 1379-1399.

Walgito, B. (2010). Pengantar Psikologi Umum. Edisi kelima. Yogyakarta: Andi Offset. 
Williams, B., Williams, J. \& Ullman, A. (2002). Parental involvement in education. Research Report 332. Norwich, UK: Queens printe.

Xia, T., Gu, H., \& Li, W. (2019). Effect Of Parents' Encouragement on Reading Motivation: The Mediating Effect of Reading Self-Concept and the Moderating Effect Of Gender. Journal of Frontiers in Psychology, 10, 609.

Yaumi, M. (2014). Pendidikan Karakter: Landasan, Pilar, Dan Implementasi. Jakarta: Prenada Media Grup

Yetti, R. (2012). Pengaruh Keterlibatan Orang Tua Terhadap Minat Membaca Anak Ditinjau Dari Pendekatan Stres Lingkungan. Jurnal Ilmu Pendidikan, 9(1), 17-28.

Zhou, N., \& Yadav, A. (2017). Effects Of Multimedia Story Reading and Questioning On Pre-Schoolers' Vocabulary Learning, Story Comprehension And Reading Engagement. Journal Of Educational Technology Research And Development, 65(6), 1523-1545. 